\title{
Strategi Pengembangan Objek Wisata Gembira Loka Zoo Melalui Pendekatan Swot Analysis
}

\author{
Dyah Fitriani dan Hendro Setyono \\ Fakultas Ekonomi dan Bisnis, Universitas Ahmad Dahlan, Indonesia \\ Email: dyah.fitriani@mgm.uad.ac.id/hendro.setyono@mgm.uad.ac.id
}

\begin{abstract}
ABSTRAK
Gembira Loka Zoo menjadi salah satu objek wisata di Kota Yogyakarta yang sangat diminati. Koleksi binatang yang banyak dan beragam menjadi salah satu daya tariknya. Selain itu beberapa atraksi yang diselenggarakan di Gembira Loka Zoo juga banyak diminati pengunjung. Di sisi lain keberadaan objek wisata serupa seperti Taman Safari, Mini Zoo dan beberapa desa wisata yang mengusung tema wisata alam perlu menjadi perhatian untuk perbandingan daya saing Gembira Loka Zoo.Tujuan penelitian ini adalah untuk mengetahui kekuatan, kelemahan, peluang dan ancaman serta strategi pengembangan Gembira Loka Zoo. Perumusan strategi pengembangan Gembira oka Zoo diawali dengan SWOT Analysis. SWOT Analysis digunakan untuk mengevaluasi kekuatan, kelemahan, peluang, dan ancaman yang dihadapi Gembira Loka Zoo. Setelah SWOT Analysis dilaksanakan, barulah dapat dirumuskan strategi pengembangan Gembira Loka Zoo.
\end{abstract}

Kata kunci: kekuatan, kelemahan, peluang, ancaman, strategi pengembangan

\section{PENDAHULUAN}

Visi Pembangunan Kepariwisataan Daerah Istimewa Yogyakarta sesuai dengan RIPPARDA Tahun 2012-2025, yaitu "Terwujudnya Yogyakarta sebagai destinasi pariwisata berbasis budaya terkemuka di Asia Tenggara, berkelas dunia, berdaya saing, berkelanjutan, mampu mendorong pembangunan daerah untuk kesejahteraan masyarakat. Beragam jenis pariwisata ada di Kota Yogyakarta, seperti wisata sejarah, wisata pendidikan, wisata budaya, wisata kuliner, dan event tourism. Citra Kota Yogyakarta sebagai daerah tujuan wisata masih kalah dibandingkan Bali. Wisatawan nusantara maupun mancanegara masih menjadikan Bali sebagai daerah tujuan wisata. Dari tarik Bali diantaranya pada wisata alam dan wisata budaya. Terkait visi 'berdaya saing', Yogyakarta memiliki peluang pada event tourism. Event tourism yang rutin diselenggarakan di Kota Yogyakarta adalah sekaten, gunungan, kampung imlek, pasar sore Ramadhan kampung Kauman, Festival Kesenian Yogyakrta (FKY) dan Kustomfest. Peluang masih terbuka lebar di bidang Event Tourism.

Jumlah kunjungan wisatawan di DIY hingga saat ini belum mencapai target tahun 2017. Kunjungan wisatawan ke DIY tahun 2017 untuk wisatawan nusantara 4,9 juta dan wisatawan mancanegara 385. Kepala Dinas Pariwisata DIY Aris Riyanta mengatakan hitungan hingga November baru tecapai $90 \%$. Target diharapkan dapat terpenuhi pada libur akhir tahun Desember 2017 ini. Karena menurut Aris banyak orang pada bulan ini melakukan perjalanan untuk liburan ke Yogyakarta. "Jumlah wisatawan di 2017 ini belum tercapai targetnya. Harapanya tercover di Desember ini," kata Aris Riyanta di DPRD DIY, Jalan Malioboro, Yogyakarta. Aris optimis kunjungan wisatawan di DIY akan meningkat pada tahun 2018. Pada tahun 2018 kunjungan wisatawan di DIY ditargetkan meningkat 10-15\% (https://news.detik.com). Terkait dengan event tourism, beberapa event tourism di Kota Yogyakarta masih perlu ditingkatkan pengelolaannya. Event tourism masih terbatas 
pengunjungnya, mayoritas wisatawan nusatara dan terutama masyarakat Kota Yogyakarta. Wisatawan manca negara tidak banyak yang mengetahui event-event tersebut.

Banyak seniman yang tinggal di Yogyakarta. Seniman tergolong masyarakat yang memiliki ide kreatif yang terkait dengan seni. Sebagai kota pelajar, Yogyakarta juga memiliki banyak anak muda dengan berbagai ide kreatifnya. Kekuatan ini dapat dimanfaatkan untuk mengembangkan event tourism di Yogyakarta. Namun di sisi lain, event tourism di Yogyakarta belum terkonsep dengan baik. Tentu saja ini menjadi kelemahan dalam pengembangan event tourism di Yogyakarta.

Bali merupakan daerah tujuan wisata nomor satu di Indonesia. Bali dan Yogyakarta sebenarnya memiliki beberapa kesamaan diantaranya memiliki warisan budaya yang masih dilestarikan sampai saat ini dan memiliki banyak seniman. Hal ini merupakan peluang bagi Yogyakarta untuk menjadi daerah tujuan wisata yang dapat disejajarkan dengan Bali. Namun pengembangan event tourism dapat saja terkendala dengan masuknya budaya-budaya asing.

\section{Pengertian Perilaku Konsumen}

Pengertian perilaku konsumen seperti yang diungkapkan Schifman, Kanuk, dan Wisenblit (2010) dalam Tjiptono (2011) yaitu perilaku yang ditunjukkan konsumen dalam mencari, membeli, menggunakan, mengevaluasi dan menghentikan konsumsi produk dan jasa yang mereka harapkan dapat memuaskan kebutuhan mereka. Perspektif riset perilaku konsumen menurut Kotler dan Keller (2009) terdiri dari :

1. Perspektif pengambilan keputusan. Perspektif ini menggambarkan seorang konsumen sedang melakukan serangkaian langkah-langkah tertentu pada saat melakukan pembelian.Langkah-langkah ini termasuk pengenalan masalah, mencari evaluasi alternative, dan evaluasi pasca perolehan.

2. Perspektif pengalaman. Perspektif ini menganggap bahwa untuk beberapa hal konsumen tidak melakukan pembelian sesuai dengan proses pengambilan keputusan yang rasional. Namun mereka membeli produk dan jasa tertentu untuk memperoleh kesenangan, menciptakan fantasia tau perasaan emosi saja. Pengklasifikasian berdasarkan perspektif pengalaman menyatakan bahwa pembelian akan dilakukan karena dorongan hati dan mencari variasi.

3. Perspektif pengaruh perilaku. Perspektif ini mengasumsikan bahwa kekuatan lingkungan memaksa konsumen untuk melakukan pembelian tanpa harus terlebih dahulu membangun kepercayaan terhadap produk. Menurut perspektif ini, konsumen tidak saja melalui proses pengambilan keputusan rasional, namun juga bergantung pada perasaaan untuk membeli produk dan jasa tersebut. Sebagai gantinya, tindakan pembelian konsumen secara langsung merupakan hasil dari kekuatan lingkungan, seperti sarana promosi penjualan, nilai-nilai budaya, lingkungan fisik, dan tekanan ekonomi.

\section{Proses Pengambilan Keputusan Konsumen}

Konsumen mengambil keputusan pembelian melalui tiga tahap yaitu : pra-pembelian, konsumsi, dan evaluasi purna beli. Penjelasan ketiga tahap tersebut sebagai berikut :

1. Tahap Pra-Pembelian

1) Identifikasi Kebutuhan. Proses pembelian diawali ketika seseorang mendapatkan stimulus (pikiran, tindakan atau motivasi) yang mendorong dirinya untuk mempertimbangkan pembelian barang atau jasa. Stimulus dapat berupa commercial cues atau social cues. Commercial cues adalah kejadian atau motivasi yang memberikan stimulus bagi konsumen untuk melakukan pembelian, sebagai usaha promosi perusahaan. Sedangkan social cues adalah stimulus yang didapatkan dari kelompok referensi yang dijadikan panutan atau acuan oleh seseorang. 
2) Pencarian Informasi. Dalam hal attribute searchability jasa berbeda secara signifikan dengan barang fisik, yaitu search properties, experience properties dan credence properties. Search properties adalah fitur-fitur yang memungkinkan pelanggan untuk mengevaluasi produk sebelum pembelian dilakukan. Experience properties merupakan atribut-atribut yang hanya bias dievaluasi selama pembelian dan konsumsi. Sedangkan credence properties adalah karakteristik-karakteristik yang sulit atau bahkan tidak mungkin dievaluasi konsumen secara meyakinkan, bahkan sekalipun setelah dibeli dan dikonsumsi.

3) Evaluasi Alternatif. Atribut yang biasa digunakan konsumen untuk mengevaluasi jasa adalah atribut biaya, atribut kinerja, atribut social, dan atribut ketersediaan

2. Tahap Konsumsi. Mood dan emosi dapat membuat penilaian pelanggan jasa terhadap service encounter dari penyedia jasa menjadi bias. Mood dan emosi dapat memperkuat pengalaman jasa dan membuatnya lebih positif atau lebih negative dari yang sesungguhnya terjadi. Bagi karyawan, mood juga berpengaruh pada cara berinteraksi dengan pelanggan, misalnya tutur bahasa, ekspresi wajah, gerakan tubuh, dan seterusnya.

3. Tahap Evaluasi Purna Beli. Evaluasi purna beli dapat menggunakan model gap antara ekspektasi dan persepsi. Semakin besar gap negative (persepsi-ekspektasi) yang ada maka semakin negative evaluasi pembelian. Sebaliknya, jika gap negative tersebut semakin kecil atau malah menjadi gap positif maka evaluasi pembelian akan semakin positif.(Tjiptono, 2011)

\section{Profil Wisatawan}

Salah satu tren yang menonjol dalam perkembangan pasar wisatawan adalah pergeseran preferensi aktivitas dan destinasi pariwisata akibat perubahan faktor psikografis. Hal ini terlihat dari perubahan selera, minat, ekspektasi, dan pola konsumsi, serta kepuasan wisatawan. Psikografis wisatawan terbagi menjadi tiga, yaitu :

1. Psychocentric/Dependable yaitu wisatawan yang sangat tergantung, pasif, dan atau kurang mobile dan suka mencari kenyamanan dan kesamaan-kesamaan. Mereka ini adalah wisatawan pemula atau belum begitu berpengalaman.

2. Mid-centric adalah wisatawan yang yang suka berwisata dan dalam beberapa hal suka perbedaan dengan situasi di daerah asal, tetapi relatif kurang kritis terhadap produk wisata yang dijual.

3. Allocentric/venturer yaitu wisatawan yang memiliki kepribadian terbuka, suka tantangan, aktif dan selalu mencari pengalaman yang serba unik.

Selain profil psikografis yang mengalami pergeseran, perubahan profil demografi dan profil sosial juga signifikan berubah. Dari sisi demografis porsi penduduk lansia atau berusia lebih dari 65 tahun semakin banyak. Kondisi kesehatan mereka tergolong baik dengan kecukupan layanan asuransi dan jaminan sosial yang hampir penuh. Profil sosial berubah seiring dengan perkembangan teknologi yang mempengaruhi pembentukan persepsi wisatawan. Teknologi informasi yang semakin intensif memudahkan calon wisatawan memperoleh informasi yang semakin lengkap, rinci dan valid tentang produk-produk pariwisata Damanik (2013).

\section{Konsep dan Parameter Daya Saing}

Damanik (2013) menyatakan bahwa upaya untuk meningkatkan daya saing destinasi pariwisata bukanlah tanpa dasar teoritik dan empirik. Beberapa ahli pemasaran pariwisata meyakini tindakan ini sebagai pilihan strategis. Berikut ini beberapa parameter yang menentukan daya saing pariwisata suatu daerah : 
1. Harga. Komponen harga meliputi akomodasi, perjalanan, persewaan angkutan, hiburan, biaya hiburan, dan sebagainya.

2. Keterbukaan mengacu pada kesediaan menerima dan melakukan transaksi perdagangan secara internasional, termasuk kemudahan dalam urusan keimrigasian dan perpajakan.

3. Infrastruktur. Komponen infrastruktur terdiri dari kemudahan akses terhadap fasilitas publik dan pariwisata, jaringan transportasi, fasilitas sanitasi, dan air minum.

4. Lingkungan. Pariwisata sering disebut sebagai green industry, dibandingkan dengan jenis industri lain, karena secara umum relatif lebih ramah lingkungan dan memiliki potensi sebagai alat untuk konservasi sumber daya alam.

5. Teknologi. Teknologi telah mengubah peradaban manusia dalam kurun waktu yang pendek. Ketersediaan produk teknologi memungkinkan komunikasi antar manusia dapat berlangsung secara intensif dan efisien.

6. Sumber Daya Manusia (SDM). Kualitas SDM diukur melalui indicator harapan hidup, angka buta huruf, pendidikan, pengangguran, pelatihan, ketrampilan, dan gender.

7. Human Tourism. Human Tourism Index menunjukkan keterkaitan langsung antara pariwisata dengan kesejahteraan masyarakat. Pembangunan Sosial. Indeks pembangunan sosial mengacu pada Indeks Pembangunan Manusia (IPM). Indikator yang digunakan adalah usia harapan hidup, pendidikan, pendapatan, rasio personal commputer per 1.000 penduduk, rasio surat kabar per 1.000 penduduk, dan rasio televisi per 1.000 penduduk

Tujuan penelitian ini adalah untuk mengetahui kekuatan, kelemahan, peluang dan ancaman yang dihadapi Gembira Loka Zoo serta merumuskan stategi pengembangan Gembira Loka Zoo.

Purnomo (2009) meneliti tentang Strategi Pemasaran Produk Wisata Minat Khusus Goa Cerme, Imogiri, Bantul. Hasil penelitian tersebut diantaranya adalah karakteristik pasar untuk wisata khusus Goa Cerme adalah berumur muda dan terpelajar. Motif utama kegiatan petualangan, pengeluaran masih sedikit karena umumnya pelajar belum bekerja, dan datang secara berombongan. Jumlah wisatawan masih jauh dari kapasitas efektifnya. Para wisatawan menginginkan perjalanan berkualitas, mencari sesuatu yang baru dan dapat memperluas pengalaman

Zoun, Maungbe, Deng dan Selin (2015) menggunakan Teknik AHP (Analytic Hierarchy Programme) untuk menilai daya saing West Virginia dibandingkan dengan kota sekitar. Penelitian tersebut menyatakan bahwa daya pikat West Virginia adalah pada wisata alam dan wisata petualangan. West Virginia unggul dalam hal keramahan warganya, keamanan dan keselamatan, dan harga-harga barang yang terjangkau. Namun West Virginia memiliki kelemahan dalam hal kualitas restoran, keragaman kuliner, dan ketersediaan area bermain untuk anak-anak.

Adongo, Anuga dan Dayour (2015) meneliti mengenai perilaku wisatawan asing terhadap kuliner khas Ghana. Penelitian tersebut menyimpulkan bahwa pengalaman dalam merasakan kuliner dapat menjadi sarana pemasaran. Pengalaman kuliner didasari oleh faktor budaya, pendidikan, kebaruan, hedonism, dan pengalaman kuliner sebelumnya. Kesan yang mendalam mengenai kuliner khas Ghana juga menyebabkan wisatawan bersedia merekomendasikan kuliner tersebut kepada orang lain.

Mody, Day, Sindor dan Jaffe (2015) meneliti mengenai perbedaan motivasi wisatawan asing dan wisatawan lokal. Hasil penelitian mereka menjelaskan bahwa motivasi wisatawan terbagi menjadi 3 (tiga) kelompok yaitu : Responsibles, Novelty Seekers, dan Socializers.

Rahayu dan Hariadi (2014) meneliti mengenai perilaku belanja turis individual atas produk batik di Pulau Madura. Temuan penelitian tersebut adalah pembeli batik adalah kelompok masyarakat menengah ke atas yang menyukai batik tulis dalam bentuk pakaian 
jadi. Rekomendasi dari penelitian mereka adalah untuk membangun sentra batik di Bangkalan dekat dengan Jembatan Suramadu.

\section{METODE PENELITIAN}

Populasi penelitian ini adalah wisatawan nusantara baik pria maupun wanita yang berkunjung ke Gembira Loka Zoo. Sampel penelitian ini sebagian wisatawan nusantara baik pria maupun wanita yang berkunjung ke Gembira Loka Zoo .Teknik pengambilan sampel yang digunakan adalah purposive sampling yaitu metode pengambilan sampel dengan mempertimbangkan kriteria-kriteria tertentu. Sampel penelitian ini adalah wisatawan yang berkunjung ke Daerah Istimewa Yogyakarta dengan kriteria sebagai berikut : berwisata baik dalam kelompok kecil atau pribadi bukan dalam rombongan besar seperi rombongan rekreasi sekolah dan berusia minimal 17 tahun. Teknik pengumpulan data penelitian ini berupa kuesioner dan observasi lapangan.

\section{HASIL DAN PEMBAHASAN}

Tabel 1. Hasil Analisis SWOT Gembira Loka Zoo

\begin{tabular}{|c|c|c|}
\hline Keterangan & Rata-Rata & Rerata \\
\hline \multicolumn{3}{|l|}{ Produk } \\
\hline Bersih & 3,7 & \multirow{5}{*}{3,6} \\
\hline Nyaman & 3,7 & \\
\hline Aman & 3,7 & \\
\hline Kelayakan kandang & 3,4 & \\
\hline Kecocokan sebagai wisata edukasi & 3,6 & \\
\hline \multicolumn{3}{|l|}{ R } \\
\hline Harga tiket masuk terjangkau & 3,5 & \multirow{6}{*}{3.3} \\
\hline Harga tiket masuk sesuai fasilitas yang tersedia & 3,4 & \\
\hline Harga tiket wahana terjangkau & 3,2 & \\
\hline Harga makanan dan minuman terjangkau & 3.0 & \\
\hline Sistem pembayaran mudah & 3,7 & \\
\hline Harga souvenir / merchandise terjangkau & 2,8 & \\
\hline \multicolumn{3}{|l|}{ 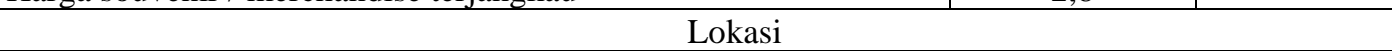 } \\
\hline Lokasi mudah diakses & 3,4 & \multirow{5}{*}{3,4} \\
\hline Kondisi jalan menuju GLZ bagus & 3,3 & \\
\hline Lingkungan sekitar GLZ nyaman dan bersih & 3,3 & \\
\hline Papan petunjuk menuju GLZ jelas & 3,5 & \\
\hline Parkir luas & & \\
\hline \multicolumn{3}{|l|}{ Promosi } \\
\hline Informasi dari teman & 3,3 & \multirow{4}{*}{3,4} \\
\hline Banyak paket promosi dan diskon & 3,2 & \\
\hline Citra GLZ sebagai objek wisata terkenal di Jawa & 3,3 & \\
\hline Citra GLZ sebagai objek wisata yang baik di masyarakat & 3,9 & \\
\hline \multicolumn{3}{|c|}{ Kepribadian Konsumen } \\
\hline Ada alokasi dana untuk berwisata & 3,3 & \multirow{3}{*}{3,3} \\
\hline Kebutuhan akan gaya hidup & 3,3 & \\
\hline Kebutuhan untuk hiburan & 3,2 & \\
\hline
\end{tabular}

Sumber: Data Diolah (2020) 
Berdasar data yang diperoleh maka dapat dinyatakan bahwa : kekuatan Gembira Loka Zoo (GLZ) ada pada faktor citra GLZ sebagai objek wisata yang baik di mata masyarakat, kebersihan lokasi, kenyamanan lokasi, keamanan lokasi serta sistem pembayaran yang mudah. Sedangkan kelemahan Gembira Loka Zoo ada pada faktor harga khususnya pada harga souvenir atau merchandise. Secara keseluruhan, Gembira Loka Zoo masih memiliki peluang dalam pengembangan produk karena wisatawan masih memandang Gembira Loka Zoo memiliki daya tarik tersendiri dibandingkan objek wisata lain di Jawa. Namun ada ancaman dalam hal harga dan kepribadian konsumen. Beberapa konsumen masih menilai harga tiket masuk dan harga souvenir mahal. Selain itu, mayoritas konsumen tidak menjadikan Gembira Loka Zoo sebagai prioritas objek wisata yang akan dikunjungi. Wisatawan masih memiliki banyak alternatif hiburan lain.

Strategi pengembangan Gembira Loka Zoo dapat dirumuskan sebagai berikut :

Tabel 2. Strategi Pengembangan Gembira Loka Zoo

\begin{tabular}{|c|l|l|}
\hline & Opportunities & Threaths \\
\hline$S$ & Produk perlu dikembangkan dengan & Produk yang dikembangkan \\
$t$ & menambah jumlah koleksi satwa, & GLZ mempertimbangkan selera \\
$r$ & menambah atraksi satwa dan wahana & atau minat konsumen sehingga \\
$e$ & sehingga citra GLZ di mata masyarakat & konsumen tetap berminat \\
$g$ & semakin bagus dan dapat meningkatkan & menjadikan GLZ sebagai tempat \\
$h$ & daya tarik kepada wisatawan untuk & hiburan yang menyenangkan. \\
$t$ & berkunjung ke GLZ & \\
$s$ & & \\
\hline W & Strategi harga perlu diterapkan supaya & GLZ perlu melakukan \\
$e$ & semua kalangan masyarakat dapat & benchmarking pada objek wisata \\
$a$ & menjadikan GLZ sebagai tujuan objek & sejenis terkait harga dan fasilitas \\
$k$ & wisata. GLZ perlu mempertimbangkan & sehingga dapat meningkatkan \\
$n$ & daya beli masyarakat dalam menetapkan & daya saing GLZ. Dampak \\
$e$ & harga souvenir dan harga tiket masuk. & selanjutnya wisatawan akan \\
$s$ & & loyal untuk tetap menjadikan \\
$s$ & & GLZ sebagai daerah tujuan \\
$e$ & & wisata. \\
$s$ & & \\
\hline
\end{tabular}

Sumber : Data Diolah (2020)

\section{KESIMPULAN}

Kekuatan Gembira Loka Zoo (GLZ) ada pada faktor citra GLZ. Sedangkan kelemahan Gembira Loka Zoo ada pada faktor harga. Secara keseluruhan, Gembira Loka Zoo masih memiliki peluang dalam pengembangan produk karena wisatawan masih memandang Gembira Loka Zoo memiliki daya tarik tersendiri dibandingkan objek wisata lain di Jawa. Namun ada ancaman dalam hal harga dan kepribadian konsumen.

\section{DAFTAR PUSTAKA}

Adongo, Charles A. Samuel, Anuga. Frederick, Dayour. 2015. Will they tell others to taste? International tourists' experience of Ghanaian cuisines Tourism Management Perspectives. Volume 15, July 2015, Pages 57-64 Confederation Of Tourism And Hospitality. 2011. Special Interest Tourism. London : BPP Leaning Media

Damanik, Janianto. 2013. Pariwisata Indonesia Antara Peluang dan Tantangan. Yogyakarta: Pustaka Pelajar

Hariadi, Sugeng. Rahayu, Siti. 2013. Perilaku Belanja Turis Individual Atas Produk Batik di Pulau Madura. Jurnal Bisnis dan Ekonomika. Surabaya : Universitas Surabaya 
Hamzehpour, Farhad, Behram Ranjbarian, Saeid Fathi, Azarnoosh Ansari . 2019. The Strategic SWOT Analysis to Use Social Marketing in the Design of the Research Development Model of Islamic Azad University. The International Journal of Humanities. Volume 26, Issue 3 (2019), Pages 1-105.

Kotler, Philip, Keller, Kevin Lane. 2009. Manajemen Pemasaran (Edisi Kedua Belas).Cetakan Ketiga. Jakarta : PT. Indeks

Mody, Makarand. Jonathan, Day, Sandra, Syndor. William, Jaffe. 2015. The different shades of responsibility: Examining domestic and international travelers' motivations for responsible tourism in India. Tourism Management Perspectives. Volume 12, October 2014, Pages 113-124

Oktarinda, Anggi. 2014. Yogyakarta Dorong Diversifikasi Wisata. Didapatkan dari http://kabar24.bisnis.com. 4 Desember 2014. Jam 17.00

Purnomo, Cahyo. 2009. Strategi Pemasaran Produk Wisata Minat Khusus Goa Cerme, Imogiri, Bantul. Jurnal Karisma. Vol. 3(2): 99-112. Yogyakarta : UPN

Teimoori, Dorna, Alireza Alinezhad. 2019. Organizational Sustainable Competitive Advantage Using ORESTE, TRIZ, SWOT Approaches in Gray Conditions. Iranian Journal of Optimization. Volume 11, Issue 2, 2019, 85-96

Tjiptono, Fandi. 2011. Pemasaran Jasa. Yogyakarta : Banyu Media

Widiyanto, Danar. 2015. Kunjungan Wisatawan 2014 Lampaui Target. Didapatkan dari http://krjogja.com. 6 Februari 2015. Jam 16.05

Zoun, Yanhong. Maumbe, Kudzayi. Deng, Jinyang. Selin, Steven W. 2015. Resourcebaseddestination ompetitiveness evaluation using a hybrid analytic hierarchy process (AHP): The case study of West Virginia. Tourism Management Perspectives. Volume 15. July 201. 